\title{
A comparative study of lipid composition of an under- valued crustacean (Munida spp.) captured in winter and summer
}

\author{
Bibiana García-Soto ${ }^{1}$, Marcos Trigo ${ }^{2}$, Jorge Barros-Velázquez ${ }^{3}$ \\ and Santiago P. Aubourg, ${ }^{2, *}$
}

${ }^{1}$ Cooperativa de Armadores de Pesca del Puerto de Vigo (ARVI), Puerto Pesquero s/n 36202-Vigo (Spain)

${ }^{2}$ Department of Food Science and Technology, Marine Research Institute (CSIC), c/E. Cabello, 6, 36208-Vigo (Spain).

${ }^{3}$ Department of Analytical Chemistry, Nutrition and Food Science, School of Veterinary Sciences, University of Santiago de Compostela, 27002-Lugo (Spain)

* Corresponding author: saubourg@iim.csic.es

\section{$\underline{\text { Acknowledgments }}$}

This work was supported by the Secretaría Xeral de I+D from the Xunta de Galicia (Galicia, Spain) through the Research Project (2012-2014) IN 841C 2012/82. The authors thank Mrs. Montserrat López Ramírez for her excellent technical assistance and the owners and crew of the vessel "Nuevo San Cibrán" for providing the lobster krill specimens. 


\section{A comparative study of lipid composition of an under-valued crustacean (Munida} spp.) captured in winter and summer

\section{ABSTRACT}

This research was focused on the lipid fraction of an under-valued crustacean (lobster krill; Munida spp.), being its basic objective the comparative study of individuals captured at winter and summer seasons. For this purpose, seasonal variations were analysed in the muscle (i.e., tail meat) for proximate composition, lipid classes distribution and fatty acids profile. As a result, mean total lipids ranged from $0.75 \pm 0.08 \%$ (summer) to $0.92 \pm 0.06 \%$ (winter), moisture from $77.94 \pm 0.25 \%$ (winter) to $78.62 \pm 0.38 \%$ (summer) and protein from $17.93 \pm 0.46 \%$ (summer) to $18.22 \pm 0.46 \%$ (winter). Concerning lipid classes content ( $\%$ of total lipids), phospholipids ranged from $64.85 \pm 1.29$ (summer) to $67.85 \pm 2.56$ (winter), sterols from $12.15 \pm 0.35$ (winter) to $13.54 \pm 0.54$ (summer), triacylglycerols from $0.04 \pm 0.02$ (summer) to $1.25 \pm 0.88$ (winter) and free fatty acids from $1.14 \pm 0.72$ (winter) to $2.19 \pm 0.34$ (summer). In both seasons, the most abundant fatty acids (FA) were C22:6 $13, \mathrm{C} 16: 0, \mathrm{C} 18: 1 \omega 9$ and $\mathrm{C} 20: 5 \omega 3$. PUFA were found as the most abundant group in individuals from both seasons (50.4$55.3 \%$ ). Higher PUFA values were determined in summer samples, while a highlyvaluable $\omega 3 / \omega 6$ ratio (from $9.11 \pm 1.12$ in summer to $10.40 \pm 1.39$ in winter) was observed. It is concluded that in spite of being a low-fat product, the lipid fraction of this under-utilised crustacean can provide highly-valuable constituents.

Running head: Munida spp. lipids in winter and summer

$\underline{\text { Key words: }}$ Lobster krill; tail muscle; seasonal variations; proximate composition; lipid classes; fatty acids 
Seafood products are known to provide great amounts of different beneficial

nutrients such as highly-nutritional and digestible proteins, lipid-soluble vitamins, essential minerals and highly unsaturated fatty acids (Simopoulos, 1997; Ortiz et al., 2013). Marine lipids are now the subject of a great deal of attention due to their high content of $\omega 3$ polyunsaturated fatty acids (PUFA). Among such fatty acids, a great attention has been accorded to the two most abundant components, i.e., C22:6 103 (docosahexaenoic acid, DHA) and C20:5 03 (eicosapentaenoic acid, EPA) (Sveinsdóttir et al., 2016). Thus, C22:6 133 has been reported to contribute to the development of certain physiological functions related to the nervous system and visual functions in human beings (Linko and Hayakawa, 1996), while C20:503 has been reported to be beneficial for human health as it reduces the risk of cardiovascular diseases (Hall et al., 2008).

Marine species have shown wide lipid content variations as a result of endogenous and exogenous effects (Pearson et al., 1977; Piclet, 1987). On one hand, lipid matter has been described to exhibit a heterogeneous distribution throughout the body of marine species, probably affected by physiological factors (Sieiro et al., 2006). On the other hand, seasonal variation was considered to play a key role on temperature, feeding availability and other external factors affecting lipid content in different types of marine species (Bandarra et al., 2001). Consequently, an important effect of the seasonal variation on the level of lipid damage has been reported in processed marine species (Aubourg, 1999; Romotowska et al., 2016).

The marine food industry is suffering from dwindling stocks of traditional species as a result of drastic changes in their availability and legal limitations in their capture. Thus, seafood manufacturers and technologists are according an increasing 
51 attention to new and non-conventional sources. Among them, lobster krill, also called 52 squat lobster, a decapod crustacean belonging to the genus Munida (Family

Galatheidae, Order Decapoda), represents a relevant and promising choice. Lobster krill lives mainly in the Atlantic Ocean, but is also abundant at deep Mediterranean bottoms. Biological and ecological items of different species belonging to this genus have been described previously (Freire et al., 1992; Company et al., 2003). Currently, lobster krill has no commercial value, but it is occasionally caught and discarded at sea during fishing targeted to other commercial fish species. Estimations from the Spanish Institute of Oceanography (IEO) for the period 2004-2008 have indicated that Munida spp. represent around $6 \%$ of total discard weight in trawl fisheries targeting demersal species in the Northern Spanish coast (Pérez et al., 2008; García-López et al., 2016). Concerning previous technological studies, Munida spp. have shown a promising behaviour under chilling (García-Soto et al., 2015a) and frozen (García-Soto et al., 2015b) storage. Additionally, recent studies on their carotenoid composition (GarcíaLópez et al., 2016) and proteolytic activity (D’Ambrosio et al., 2003) have opened the way to other issues of technological interest.

The present research was focused on the study of the lipid fraction of Munida spp. The basic objective of this study was to carry out a comparative study between individuals captured at winter and summer seasons. Seasonal variations were analysed in the muscle (i.e., tail meat) in proximate composition, lipid classes distribution and fatty acids profile. 
75

76

77

\section{$\underline{\text { Raw material and sampling }}$}

Lobster krill was caught near the Galician Atlantic coast (North-Western Spain) in winter (January 2013) and summer (July 2013), stored on-board and transported to the laboratory. Throughout this process (about ten hours), Munida individuals were kept in ice. Munida specimens were characterised in terms of species identification, length and weight. Thus, individuals employed in the study were catalogued as included in the following species: M. sarsi, M. tenuimana, M. rugosa and M. microphtalma, being $M$. sarsi the most abundant. Further, carapace length and total weight were included in the following ranges: $3.2-4.3 \mathrm{~cm}$ and 9.5-11.0 g, respectively. Then, the edible flesh (i.e., tail muscle) was separated and used to undertake the different chemical analyses. At each season, $1.5 \mathrm{~kg}$ of lobster krill specimens were divided into three different groups of $0.5 \mathrm{~kg}$ each $(\mathrm{n}=3)$. In each group, the edible flesh of all individuals was pooled together and analysed independently.

All chemical analyses were carried out on the lobster krill muscle in triplicate. All solvents and chemical reagents used were of reagent grade (Merck, Darmstadt, Germany).

\section{$\underline{\text { General composition analysis }}$}

The total lipid fraction was extracted from the Munida muscle by the Bligh and Dyer (1959) method, which employs a single-phase solubilisation of the lipids using a chloroform-methanol (1:1) mixture. Results were expressed as \% on wet muscle basis. Throughout the study, lipid extracts were kept at $-40^{\circ} \mathrm{C}$ under nitrogen atmosphere. 
Moisture content was determined as the weight difference in the Munida muscle

(1-2 g) before and after $4 \mathrm{~h}$ at $105^{\circ} \mathrm{C}$ (AOAC, 1990). Results were expressed as \% on wet muscle basis.

Protein content was determined in the Munida muscle using the Kjeldahl method (AOAC, 1990) with a conversion factor of 6.25. Results were expressed as \% on wet muscle basis.

\section{Lipid classes analysis}

Phospholipids (PL) were determined by measuring the organic phosphorus in the total lipid extracts according to the Raheja et al. (1973) method, which is based on a complex formation with ammonium molybdate. Results were expressed as $\%$ of total lipid.

Sterols (ST) were determined on total lipid extracts by the method of Huang et al. (1961), based on the Liebermann-Buchardt reaction. Results were expressed as \% of total lipid.

To measure the triacylglycerols (TAG) content, the total lipid extracts were first purified on $20 \times 20 \mathrm{~cm}$ thin-layer chromatography plates coated with a $0.5 \mathrm{~mm}$-layer of silica gel G from Merck (Darmstadt, Germany) using a mixture of hexane-ethyl etheracetic acid (90:10:1, v:v:v; two times) as eluent (Álvarez et al., 2009). Once the TAG fraction was purified, the method of Vioque and Holman (1962) was used to measure the ester linkage content according to the conversion of the esters into hydroxamic acids and subsequent complexion with Fe (III). Results were expressed as \% of total lipid.

Free fatty acids (FFA) content was determined in the total lipid extracts following the Lowry and Tinsley (1976) method, which is based on the formation of a 
complex with cupric acetate-pyridine. In this study, benzene was replaced by toluene as organic solvent. Results were expressed as \% of total lipid.

\section{$\underline{\text { Fatty acid (FA) analysis }}$}

Total lipid extracts were converted into fatty acid methyl esters (FAME) by reaction with acetyl chloride. FAME were then analysed by Gas-Liquid chromatography (Perkin-Elmer 8700 gas chromatograph). For it, a fused silica capillary column SP-2330 (0.25 mm i.d. x 30 m, $0.20 \mu \mathrm{m}$ film, Supelco Inc., Bellefonte, PA, USA), using nitrogen at $10 \mathrm{psi}$ as carrier gas (linear flow rate of $1.0 \mathrm{ml} / \mathrm{min}$ ) and a flame ionisation detector (FID) at $250^{\circ} \mathrm{C}$ were employed (Prego et al., 2012).

Qualitative analysis was carried out by comparison with the retention times of two standard mixtures (Qualmix Fish, Larodan, Malmo, Sweden; FAME Mix, Supelco Inc., Bellefonte, PA, USA). Peak areas were automatically integrated, being C19:0 fatty acid employed as the internal standard for quantification purposes. Results concerning individual FA and FA groups were expressed as $\%$ of total FA. The polyene index (PI) was calculated as the following FA ratio: $(\mathrm{C} 20: 5 \omega 3+\mathrm{C} 22: 6 \omega 3) / \mathrm{C} 16: 0$.

\section{$\underline{\text { Statistical analysis }}$}

Data obtained from the different chemical analyses were subjected to the ANOVA method to explore differences as a result of the season. For this purpose, the PASW Statistics 18 software for Windows (SPSS Inc., Chicago, IL, USA) was employed. The comparison of means was performed using the least-squares difference (LSD) method. Differences between both seasons were considered significant for a confidence interval at the $95 \%$ level $(\mathrm{p}<0.05)$ in all cases. 


\section{Chemical composition}

Lipid content (\%) (Table 1) ranged from $0.75 \pm 0.08$ (summer) to $0.92 \pm 0.06$

(winter), so that higher values than those previously reported for this marine product were obtained (García-Soto et al., 2015a, 2015b). This lipid content is also higher than those determined in other crustacean species such as Norwegian lobster (Nephrops norvegicus) (0.70 \%; Tsape et al., 2010), pink shrimp (Parapenaeus longirostris) (0.35 \%; Cadun et al., 2005), shrimp (0.36\%; Penaeus brasiliensis), crab (0.49\%; Ucides cordatus) and lobster (0.66 \%; Panulirus argus) (Pedrosa and Cozzolino, 2001). However, other crustacean species such as lobster (1.00\%; Palinurus vulgaris), shrimp (1.30\%; Penaeus kerathurus) (Tsape et al., 2010) and Dungeness crab (1.00\%; Cancer magister) (King et al., 1990) have shown higher lipid contents. Concerning seasonal variation (Table 1), a higher lipid content $(\mathrm{p}<0.05)$ was obtained in winter specimens.

This result is in agreement with previous studies related to other crustacean species such as seabob shrimp (Xiphopenaeus kroyeri) (Luzia et al., 2003) and pink shrimp (Pandalus borealis and Pandalus jordani) (King et al., 1990). A higher lipid content in marine species during relatively colder periods (such as autumn and winter) has been explained on the basis of the previous prolonged effect of a rich feeding time (Piclet, 1987).

Moisture content (\%) (Table 1) ranged from $77.94 \pm 0.25$ (winter) to $78.62 \pm 0.38$ (summer), which can be considered slightly lower than those previously reported for such marine product (79-83 \%; García-Soto et al., 2015a, 2015b). However, moisture levels determined in this study can be considered similar to other crustacean species such as lobster (Panulirus argus) (Pedrosa and Cozzolino, 2001) and Dungeness crab 
171 specimens corresponding to the summer time when compared with those of winter season (Table 1). This result can be explained on the basis of an inverse ratio between moisture and lipid contents, so that higher moisture contents are found in individuals corresponding to relatively warmer seasons (Piclet, 1987). Such differences between individuals from winter and summer seasons had already been obtained in previous studies on pink shrimp (Pandalus borealis and Pandalus jordani) and other invertebrate species such as sea scallop (Argopecten grandis) and California squid (Loligo opalescens) (King et al., 1990).

The protein content $(\%)$ (Table 1) ranged from $17.93 \pm 0.46$ (summer) to $18.22 \pm 0.46$ (winter), which can allow us to conclude that Munida spp. represent an interesting source of this valuable nutritional constituent (Simopoulos, 1997; Ortiz et al., 2013). Compared to other crustacean species, protein values can be considered similar to species such as Dungeness crab (Cancer magister) and pink shrimp (Pandalus borealis and Pandalus jordani) (King et al., 1990), higher than shrimp (Penaeus brasiliensis) and crab (Ucides cordatus) (Pedrosa and Cozzolino, 2001), but lower than Norway lobster (Nephrops norvegicus) (Lourenço et al., 2009) and lobster (Panulirus argus) (Pedrosa and Cozzolino, 2001). No differences between the protein content of summer and winter specimens $(p>0.05)$ were found (Table 1$)$. No seasonal effect has also been reported for other marine species throughout the different seasons of the year (Piclet, 1987).

\section{$\underline{\text { Lipid class composition }}$}

PL content (\% of total lipid) ranged from $64.85 \pm 1.29$ (summer) to $67.85 \pm 2.56$ (winter) and showed no difference between seasons ( $>0.05$, Table 2). The predominance of PL in total lipids is in agreement with previous reports on other 
crustacean, mollusc and lean fish species (Pearson et al., 1977; Sieiro et al., 2006; Prego et al., 2012). PL are known to be important constituents of cell membranes providing a structural role in living bodies, so its presence in muscle is hardly affected by internal anatomical and physiological factors. Although FA content and composition in PL has been shown to be affected by the diet, the changes have shown to be relatively small when compared with those of depot fats (Pearson et al., 1977).

ST content (\% of total lipid) ranged from $12.15 \pm 0.35$ (winter) to $13.54 \pm 0.54$ (summer) (Table 2), similar to those reported for other crustacean species such as Norway lobster (Nephrops norvegicus), lobster (Palinurus vulgaris) and shrimp (Penaeus kerathurus) (Tsape et al., 2010). ST have been reported to contribute to functional properties and play structural roles in living bodies (Pearson et al., 1977). Previous studies on ST composition have shown that cholesterol is by far the predominant sterol in species such as Norway lobster (Nephrops norvegicus), lobster (Palinurus vulgaris), shrimp (Penaeus kerathurus) (Tsape et al., 2010), Dungeness crab (Cancer magister) and pink shrimp (Pandalus borealis and Pandalus jordani) (King et al., 1990). The results of the present study show a higher ST proportion in lipid matter when considering the summer specimens. In agreement with the above-mentioned structural role, no significant differences $(p>0.05)$ were found between individuals corresponding to both seasons when considering the ST content referred to wet muscle basis ( 0.11 vs. $0.10 \%$ for winter and summer specimens, respectively). No significant ( $>0.05)$ differences due to seasonal variability had also been found by Luzia et al. (2003) when comparing seabob shrimp (Xiphopenaeus kroyeri) caught in summer and winter seasons.

Results are very different when a depot lipid class like TAG is concerned. TAG concentrations were remarkably lower than those obtained for ST and PL, with values 
ranged from $0.04 \pm 0.02$ (summer) to $1.25 \pm 0.88$ (winter) ( $\%$ of total lipid, Table 2 ). Such

222

223

224

225

lipid class distribution is in agreement with that observed in invertebrates (Sieiro et al., 2006) and lean fish (Álvarez et al., 2009; Prego et al., 2012) species, but is considerably different to that found in fatty fish species (Pearson et al., 1977). Contrary to the results of this study, Tsape et al. (2010) found a higher TAG content in the lipid fraction of crustacean species such as Norway lobster (Nephrops norvegicus), lobster (Palinurus vulgaris) and shrimp (Penaeus kerathurus). In the current study, a significantly lower TAG content $(\mathrm{p}<0.05)$ was observed in summer specimens when compared to the winter season batch, this being in agreement with the lower lipid content found in specimens belonging to the latter season. In this sense, a direct ratio between TAG and total lipids contents has been reported in different kinds of marine species (Sieiro et al., 2006; Álvarez et al., 2009).

The FFA content ( $\%$ of total lipid) was ranged from $1.14 \pm 0.72$ (winter) to $2.19 \pm 0.34$ (summer) (Table 2), being such values similar to those determined in fresh Munida spp. in previous studies (1.14-2.12\%; García-Soto et al., 2015a, 2015b). Lower FFA values were reported, however, for other crustacean species such as Norway lobster (Nephrops norvegicus), lobster (Palinurus vulgaris) and shrimp (Penaeus kerathurus) (Tsape et al., 2010). A higher average FFA concentration was determined in summer specimens when compared with the winter season counterparts (Table 2). However, the differences were not significant $(\mathrm{p}>0.05)$. Such slight differences are in agreement with the well-known inverse ratio between total lipid and FFA contents, which has been described in fatty (Pearson et al., 1977) and lean (Álvarez et al., 2009; Prego et al., 2012) fish species. The FFA values found in the current study correspond to a very low development of lipid hydrolysis since analysis was carried out after the catching/slaughtering steps. Accordingly, the FFA values observed would correspond to 
the in vivo metabolic action of lipases and phospholipases on high-molecular-weight lipids such as TAG and PL, respectively (Sikorski and Kolakowski, 2000).

\section{Fatty acids composition}

Although the same four acids were found as the most abundant (Table 3), a

different trend was observed when considering the percentaged share of these FA in the total FA of winter specimen $(\mathrm{C} 22: 6 \omega 3>\mathrm{C} 16: 0>\mathrm{C} 18: 1 \omega 9>\mathrm{C} 20: 5 \omega 3)$ and summer specimen $(\mathrm{C} 22: 6 \omega 3>\mathrm{C} 20: 5 \omega 3>\mathrm{C} 18: 1 \omega 9>\mathrm{C} 16: 0)$. Other remarkable FA were $\mathrm{C} 18: 0$, between individuals from both seasons (Table 3$)$. Thus, a higher content $(p<0.05)$ of $\mathrm{C} 18: 1 \omega 7$ was determined in winter specimens, while $\mathrm{C} 20: 4 \omega 6, \mathrm{C} 20: 5 \omega 3$ and $\mathrm{C} 22: 5 \omega 3$ FA contents proved to be higher $(\mathrm{p}<0.05)$ in the summer counterparts. With respect to other fatty acids, higher average values of saturated (SFA) and monounsaturated (MUFA) fatty acids were found in winter season specimens, while higher average PUFA concentrations were found in summer counterparts. A previous study investigated the FA composition of a cold acetone extract of Munida muscle (García-

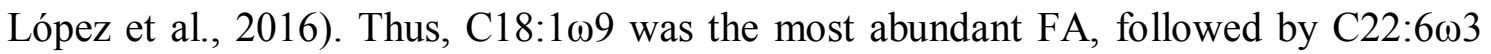
and C16:0; other remarkable FA were $\mathrm{C} 16: 1 \omega 7, \mathrm{C} 23: 0$ and $\mathrm{C} 20: 5 \omega 3$. The differences between such results and those found in the present study can be explained on the basis that different lipid extraction procedures were employed in both studies.

The results of the present study are in agreement with previous reports on the FA 267 profiles of the lipid fraction of other crustacean species. Tsape et al. (2010) found the following decreasing percentaged share for the average values of the most abundant FA

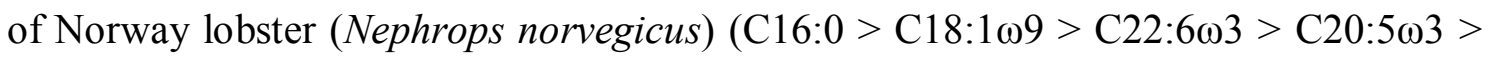


and shrimp (Penaeus kerathurus) $(\mathrm{C} 20: 5 \omega 3>\mathrm{C} 16: 0>\mathrm{C} 22: 6 \omega 3>\mathrm{C} 18: 1 \omega 9>$

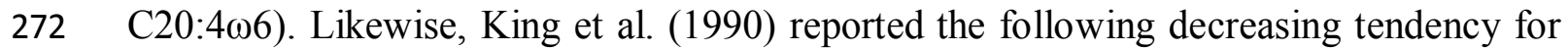
Dungeness crab (Cancer magister) $(\mathrm{C} 20: 5 \omega 3>\mathrm{C} 22: 6 \omega 3>\mathrm{C} 16: 0>\mathrm{C} 18: 1 \omega 9)$ and pink shrimp (Pandalus borealis and Pandalus jordani) (C20:5 $13>\mathrm{C} 16: 0, \mathrm{C} 22: 6 \omega 3>$ C18:109).

Previous reports on the effect of season on FA composition, such as Luzia et al. 277 (2003), did not show differences between seabob shrimp (Xiphopenaeus kroyeri)

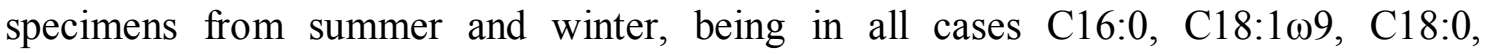
$\mathrm{C} 22: 6 \omega 3, \mathrm{C} 16: 1$ and $\mathrm{C} 20: 5 \omega 3$ the most abundant FA. However, Yanar and Çelik (2005) found different FA concentration sequences for wild shrimp (Penaeus semisulcatus) from January $(\mathrm{C} 16: 0>\mathrm{C} 20: 5 \omega 3, \mathrm{C} 22: 6 \omega 3, \mathrm{C} 18: 1 \omega 9>\mathrm{C} 18: 0>\mathrm{C} 16: 1 \omega 7)$ and July $(\mathrm{C} 18: 1 \omega 9>\mathrm{C} 16: 0>\mathrm{C} 18: 0>\mathrm{C} 20: 5 \omega 3>\mathrm{C} 16: 1 \omega 7>\mathrm{C} 20: 4 \omega 6>\mathrm{C} 22: 6 \omega 3)$, as well as for the shrimp Metapenaeus monoceros when comparing specimens caught in January $(\mathrm{C} 20: 4 \omega 6>\mathrm{C} 20: 5 \omega 3>\mathrm{C} 16: 0>\mathrm{C} 22: 6 \omega 3>\mathrm{C} 18: 0)$ and July $(\mathrm{C} 16: 0>\mathrm{C} 18: 1 \omega 9>$ $\mathrm{C} 20: 5 \omega 3>\mathrm{C} 18: 0>\mathrm{C} 16: 1 \omega 7)$.

A wide majority of the Western population does not consume adequate levels of $\omega 3$ FA through natural dietary sources, such as marine species. Accordingly, great attention has been paid to the $\omega 3 / \omega 6$ ratio of foods included in the human diet. The value of this ratio has shown to exert great effect on the development of certain health problems (Knoch et al., 2009), being the recommended ratio for the whole diet near $1 / 6$ (Simopoulos, 1994). In spite of being a low-fat product, it should be noted that in the considered beneficial for fulfilling the recommended nutritional values. 
higher SFA and MUFA average values. Differences in the PUFA and SFA

297

298

299

300

301

302

303

304

305

306

307

308

309

310

311

312

313

314

315

316

317

318

319

320 concentrations were found significant $(\mathrm{p}<0.05)$. PUFA were the major group in individuals corresponding to both seasons, reaching values ranged from $50.46 \pm 0.44$ (winter) to $55.25 \pm 0.16$ (summer). Average total $\omega 3$ - and $\omega 6$-PUFA contents were found higher in summer specimens, being differences significant $(p<0.05)$ when considering the $\omega 3$ group. Moreover, the $\omega 3 / \omega 6$ ratio ranged from $9.11 \pm 1.12$ (summer) to $10.40 \pm 1.39$ (winter), with higher average values in winter specimens. Finally, all kinds of samples revealed a high PI score, being average values higher in summer specimens, although differences were not significant $(\mathrm{p}>0.05)$. Present PI values are in agreement with those previously described in previous research concerning this marine product (2.49-2.56; García-Soto et al., 2015a, 2015b).

Previous studies focused on the lipid extract of different crustacean species revealed a similar trend for the FA groups. Thus, Tsape et al. (2010) found PUFA to be predominant in Norway lobster (Nephrops norvegicus), lobster (Palinurus vulgaris) and shrimp (Penaeus kerathurus) muscle; in such study, different $\omega 3 / \omega 6$ ratio values $(4.74$, 0.83 and 2.34, respectively) were obtained that could be explained on the basis of internal (anatomical, physiological, etc.) and external (water temperature, feeding availability, season, etc.) factors. A similar distribution of FA groups was obtained by King et al. (1990) for Dungeness crab (Cancer magister), and pink shrimp (Pandalus borealis and Pandalus jordani), being $\omega 3$ FA the most abundant PUFA in all species. Finally, Yanar and Çelik (2005) studied the seasonal variability of the FA groups distribution in two kinds of shrimp species (Penaeus semisulcatus and Metapenaeus monoceros). As a result, both species showed a higher PUFA content in specimens corresponding to January when compared with individuals from July. 
Present results have provided a first approach about the proximate and lipid compositions of this under-valued crustacean product, with a special focussing on the comparative study of individuals caught in winter and summer seasons. Thus, total lipids, moisture and protein contents ranged from 0.75 to $0.92,77.94$ to 78.62 and 17.93 to 18.22 (\% on wet muscle basis), respectively; winter specimens showed a higher $(\mathrm{p}<0.05)$ lipid content and a lower $(\mathrm{p}<0.05)$ moisture value. With respect to lipid classes, PL, ST, TAG and FFA contents ranged from 64.85 to $67.85,12.15$ to 13.54 , 0.04 to 1.25 and 1.14 to $2.19 \%$ of total lipid; the summer batch exhibited higher $(\mathrm{p}<0.05)$ ST and lower $(\mathrm{p}<0.05)$ TAG values. The most abundant FA were C22:6 03 , C16:0, C18:1 $\omega 9$ and $\mathrm{C} 20: 5 \omega 3$ in all kinds of individuals. The PUFA group was by far the most abundant in individuals from both seasons (from $50.46 \pm 0.44 \%$ in winter to $55.25 \pm 0.16 \%$ in summer). Additionally, higher PUFA values were found in summer specimens, while winter Munida spp. specimens exhibited higher saturated FA values product can be considered relatively similar to other crustacean products. In spite of being a low-fat product, the lipid fraction of this crustacean has shown to provide high proportions of highly-valuable constituents like PUFA, w3-PUFA and highly-profitable 342 FA ratios (i.e., $\omega 3 / \omega 6$ and PI), which showed no seasonal variation. Additionally, this under-utilised product has shown a profitable protein content in order to be included in the human diet as such or in combination with other food components. Further research focused on compositional issues of lobster krill is needed to explore the practical 
347 nutritious crustacean product for human consumption.

348

349

350 
352 Álvarez, V., Medina, I., Prego, R., and Aubourg, S. P. 2009. Lipid and mineral

353

354

355

356

357

358

359

360

361

362

363

364

365

366

367

368

369

370

371

372

373

374 distribution in different zones of farmed and wild blackspot seabream (Pagellus bogaraveo). Eur. J. Lipid Sci. Technol. 111: 957-966.

AOAC. 1990. Official methods for analysis of the Association of Analytical Chemistry, $15^{\text {th }}$ ed. Association of Official Chemists, Inc., Arlington, VA, USA, pp. 931937.

Aubourg, S. P. 1999. Effect of lipid damage on processed fish quality. Grasas Aceites 50: $218-224$.

Bandarra, N., Batista, I., Nunes, M., and Empis, J. 2001. Seasonal variations in the chemical composition of horse mackerel (Trachurus trachurus). Eur. Food Res. Technol. 212: 535-539.

Bligh, E., and Dyer, W. 1959. A rapid method of total extraction and purification. Can. J. Biochem. Physiol. 37: 911-917.

Cadun, A., Cakli, S., and Kisla, D. 2005. A study of marination of deepwater pink shrimp (Parapenaeus longirostris, Lucas, 1846) and its shelf life. Food Chem. 90: 53-59.

Company, J., Sardà, F., Puig, P., Cartes, J., and Palanques, A. 2003. Duration and timing of reproduction in decapod crustaceans of the NW Mediterranean continental margin: is there a general pattern? Marine Ecol. Prog. Series. 261: 201-216.

D’Ambrosio, A., Rossano, R., Ungaro, N., and Riccio, P. 2003. Proteolytic and milk clotting activities in extracts obtained from the Crustaceans Munida. J. Molec. Catal. B: Enzymatic. 865: 1-6. 
Freire, J., González-Gurriarán, E., and Olaso, I. 1992. Spatial distribution of Munida intermedia and Munida sarsi (Crustacea: Anomura) on the Galician continental shelf (NW Spain): application of geostatistical analysis. Est. Coastal Shelf Sci. 35: 637-648.

García-López, M., Pérez-Martín, R., and Sotelo, C. 2016. Carotenoid pigments composition of two commonly discarded decapod crustaceans in Grand Sole and the Galician-Northern Portugal coast fisheries. J. Aq. Food Prod. Technol. 25: 114-121.

García-Soto, B., Miranda, J. M., Barros-Velázquez, J., and Aubourg, S. P. $2015 b$. Quality changes during the frozen storage of the crustacean lobster krill (Munida spp.). Eur. J. Lipid Sci. Technol. 117: 431-439.

García-Soto, B., Miranda, J. M., Barros-Velázquez, J., and Aubourg, S. P. 2015a. Quality enhancement of the abundant under-valued crustacean, lobster krill (Munida spp.), during its chilled storage. Int. J. Food Sci. Technol. 50: 708-716.

Hall, W., Sanders, K., Sanders, T., and Chowienczyk, P. 2008. A high-fat meal enriched with eicosapentaenoic acid reduces postprandial arterial stiffness measured by digital volume pulse analysis in healthy men. J. Nutrit. 138: 287-291.

Huang, T., Chen, C., Wefler, V., and Raftery, A. 1961. A stable reagent for the Liebermann-Buchardt reaction. Anal. Chem. 33: 1405-1407.

King, I., Childs, M., Dorsett, C., Ostrander, J., and Monsen, E. 1990. Shellfish: Proximate composition, minerals, fatty acids and sterols. J. Am. Diet. Assoc. 90: $677-685$.

Knoch, B., Barnett, M., Roy, N., and McNabb, W. 2009. Study of the effects of dietary polyunsaturated fatty acids: Molecular mechanisms involved in intestinal inflammation. Grasas Aceites 60: 8-21. 
Linko, Y., and Hayakawa, K. 1996. Docosahexaenoicacid: A valuable nutraceutical? Trends Food Sci. Technol. 7: 59-63.

Lourenço, H., Anacleto, P., Afonso, C., Martins. MaF., Carvalho, MáL., Lino, A., and Nunes, MaL. 2009. Chemical characterisation of Nephrops norvegicus from Portuguese coast. J. Sci. Food Agric. 89: 2572-2580.

Lowry, R., and Tinsley, I. 1976. Rapid colorimetric determination of free fatty acids. J. Am. Oil Chem. Soc. 53: 470-472.

Luzia, L., Sampaio, G., Castellucci, C., and Torres, E. 2003. The influence of season on the lipid profiles of five commercially important species of Brazilian fish. Food Chem. 83: 93-97.

Ortiz, J., Larraín, MaA., Pacheco, N., Vivanco, J. P., Aubourg, S. P. 2013. Effect of the antioxidants profile in diet on the nutritional value retention of farmed coho salmon (Oncorhynchus kisutch) during frozen storage. Grasas Aceites 64: 311319.

Pearson, A., Love, J., and Shorland, F. 1977. "Warmed-over" flavor in meat, poultry and fish. Adv. Food Res. 23: 2-61.

Pedrosa, L., and Cozzolino, S. 2001. Centesimal and mineral composition of the raw and cooked shellfishes of the Natal-RN city. Ciênc. Tecnol. Alim. Campinas 21: 154-157.

Pérez, N., Araújo, H., and Quinzan, M. 2008. Dissemination report by the Spanish Institute of Oceanography for the Project "Estimación del descarte de las flotas de arrastre españolas en las áreas VI, VII, VIII y IX del ICES y Mediterráneo. Aproximación al descarte total por Métier. Optimización del proceso de ponderación”. Madrid, Spain: IEO. 
Piclet, G. 1987. Le poisson aliment. Composition et intérêt nutritionnel. Cah. Nutr. Diétét. XXII: 317-335.

Prego, R., Pazos, M., Medina, I., and Aubourg, S. P. 2012. Comparative chemical composition of different muscle zones in angler (Lophius piscatorius)". J. Food Comp. Anal. 28: 81-87.

Raheja, R., Kaur, C., Singh, A., and Bhatia, A. 1973. New colorimetric method for the quantitative determination of phospholipids without acid digestion. J. Lipid Res. 14: 695-697.

Romotowska, P., Karlsdóttir, M., Gudjunsdóttir, M., Kristinsson, H., and Arason, S. 2016. Influence of feeding state and frozen storage temperature on the lipid stability of Atlantic mackerel (Scomber scombrus). Int. J. Food Sci. Technol. 51: 1711-1720.

Sieiro, MP., Aubourg, S. P., and Rocha, F. 2006. Seasonal study of lipid composition in different tissues of the common octopus (Octopus vulgaris). Eur. J. Lipid Sci. Technol. 108: 479-487.

Sikorski, Z., and Kolakowski, E. 2000. Endogenous enzyme activity and seafood quality: Influence of chilling, freezing, and other environmental factors. In: Seafood enzymes. Haard, N., and Simpson, B. (Eds.) Marcel Dekker, New York, NY, USA, pp. 451-487.

Simopoulos, A. 1994. Fatty acids. In: Functional foods, designer foods, pharmafoods, nutraceuticals. Goldberg, I. (Ed.) Chapman and Hall, New York, NY, USA, pp. $355-392$.

Simopoulos, A. 1997. Nutritional aspects of fish. In: Seafood from producer to consumer, integrated approach to quality. Luten, J., Börrensen, T., and Oehlenschläger, J. (Eds.) Elsevier Science, London, UK, pp. 589-607. 
449 Sveinsdóttir, K., Martinsdóttir, E., and Ramel, A. 2016. Blood pressure-lowering effects of long chain $n-3$ fatty acids from meals enriched with liquid fish oil and from microencapsulated powder. Int. J. Food Sci. Nutr. 67: 1017-1023.

452 Tsape, K., Sinanoglou, V., and Miniadis-Meimaroglou, S. 2010. Comparative analysis of the fatty acid and sterol profiles of widely consumed Mediterranean crustacean species. Food Chem. 122: 292-299.

455 Vioque, E., and Holman, R. 1962. Quantitative estimation of esters by thin-layer 456 chromatography. J. Am. Oil Chem. Soc. 39: 63-66.

457 Yanar, Y., and Çelik, M. 2005. Seasonal variations of fatty acid composition in wild 458 marine shrimps (Penaeus semisulcatus De Haan, 1844 and Metapenaeus monoceros Fabricus, 1789) from the Eastern Mediterranean sea. Food Sci. Technol. Int. 11: 391-395.

461 


\section{TABLE 1}

Chemical composition* of Munida caught at winter and summer seasons**

\begin{tabular}{ccc}
\hline Constituent & Season \\
\hline \multirow{2}{*}{ Lipids } & Winter & Summer \\
& $0.92 \mathrm{~b}$ & $0.75 \mathrm{a}$ \\
& $(0.06)$ & $(0.08)$ \\
\hline \multirow{2}{*}{ Moisture } & $77.94 \mathrm{a}$ & $(0.38 \mathrm{~b}$ \\
& $(0.25)$ & $17.93 \mathrm{a}$ \\
\multirow{2}{*}{ Proteins } & $18.22 \mathrm{a}$ & $(0.46)$ \\
\hline
\end{tabular}

* Average values of three $(n=3)$ replicates. Standard deviations are indicated in brackets. For each constituent, average values followed by different letters $(a, b)$ denote significant differences $(\mathrm{p}<0.05)$ as a result of season.

** Values expressed as \% wet muscle weight. 


\section{TABLE 2}

Content of lipid classes* of Munida caught at winter and summer seasons**

\begin{tabular}{ccc}
\hline Lipid class & Season & \\
\hline \multirow{2}{*}{ Phospholipids } & Winter & Summer \\
& $(2.85 \mathrm{a}$ & $64.85 \mathrm{a}$ \\
& $12.15 \mathrm{a}$ & $1.29)$ \\
\hline \multirow{2}{*}{ Sterols } & $(0.35)$ & $(0.54)$ \\
& $1.25 \mathrm{~b}$ & $0.04 \mathrm{a}$ \\
\multirow{2}{*}{ Triacylglycerides } & $(0.88)$ & $(0.02)$ \\
\hline \multirow{2}{*}{ Free fatty acids } & $1.14 \mathrm{a}$ & $2.19 \mathrm{a}$ \\
& $(0.72)$ & $(0.34)$ \\
\hline
\end{tabular}

* Average values of three $(n=3)$ replicates. Standard deviations are indicated in brackets. For each lipid class or group, average values followed by different letters $(a, b)$ denote significant differences $(p<0.05)$ as a result of season.

** Values expressed as \% on lipid basis. 


\section{TABLE 3}

Fatty acid composition* of Munida caught at winter and summer seasons**

\begin{tabular}{|c|c|c|}
\hline \multirow[t]{2}{*}{ Fatty acid (FA) } & \multicolumn{2}{|c|}{ Season } \\
\hline & Winter & Summer \\
\hline C 14:0 & $\begin{array}{l}0.32 \mathrm{a} \\
(0.08)\end{array}$ & $\begin{array}{c}0.29 \mathrm{a} \\
(0.03)\end{array}$ \\
\hline C 16:0 & $\begin{array}{c}18.20 \mathrm{a} \\
(0.76)\end{array}$ & $\begin{array}{c}16.00 \mathrm{a} \\
(1.40)\end{array}$ \\
\hline C $16: 1 \omega 7$ & $\begin{array}{c}2.43 \mathrm{a} \\
(0.44)\end{array}$ & $\begin{array}{l}1.98 \mathrm{a} \\
(0.16)\end{array}$ \\
\hline C 18:0 & $\begin{array}{l}5.56 \mathrm{a} \\
(0.08)\end{array}$ & $\begin{array}{l}5.40 \mathrm{a} \\
(0.48)\end{array}$ \\
\hline C $18: 1 \omega 9$ & $\begin{array}{c}17.11 \mathrm{a} \\
(0.62)\end{array}$ & $\begin{array}{c}16.06 \mathrm{a} \\
(1.22)\end{array}$ \\
\hline C $18: 1 \omega 7$ & $\begin{array}{l}5.39 \mathrm{~b} \\
(0.29)\end{array}$ & $\begin{array}{c}.49 \mathrm{a} \\
(0.42)\end{array}$ \\
\hline C $18: 2 \omega 6$ & $\begin{array}{l}1.01 \mathrm{a} \\
(0.06)\end{array}$ & $\begin{array}{l}1.17 \mathrm{a} \\
(0.08)\end{array}$ \\
\hline C 20:1 $\omega 9$ & $\begin{array}{l}0.53 \mathrm{a} \\
(0.09)\end{array}$ & $\begin{array}{l}0.53 \mathrm{a} \\
(0.04)\end{array}$ \\
\hline C $20: 4 \omega 6$ & $\begin{array}{l}3.42 \mathrm{a} \\
(0.11)\end{array}$ & $\begin{array}{l}4.30 \mathrm{~b} \\
(0.32)\end{array}$ \\
\hline C $20: 5 \omega 3$ & $\begin{array}{c}16.87 \mathrm{a} \\
(0.16)\end{array}$ & $\begin{array}{c}19.95 \mathrm{~b} \\
(1.72)\end{array}$ \\
\hline C $22: 5 \omega 3$ & $\begin{array}{l}0.37 \mathrm{a} \\
(0.04)\end{array}$ & $\begin{array}{c}0.45 \mathrm{~b} \\
(0.01)\end{array}$ \\
\hline C $22: 6 \omega 3$ & $\begin{array}{c}28.79 \mathrm{a} \\
(0.30)\end{array}$ & $\begin{array}{c}29.38 \mathrm{a} \\
(3.11)\end{array}$ \\
\hline
\end{tabular}

* Average values of three $(n=3)$ replicates. Standard deviations are indicated in brackets. For each FA, average values followed by different letters $(a, b)$ denote significant differences $(\mathrm{p}<0.05)$ as a result of season.

** Values expressed as $\%$ of total FA. 


\section{TABLE 4}

Content and ratios* of fatty acid groups of Munida caught at winter and summer seasons $* *$

\begin{tabular}{ccc}
\hline Fatty acid group & Season & \\
\hline \multirow{2}{*}{ Total saturated fatty acids } & $24.08 \mathrm{~b}$ & Summer \\
& $(0.08)$ & $21.69 \mathrm{a}$ \\
& $25.46 \mathrm{a}$ & $(0.03)$ \\
\hline Total monounsaturated & $(0.83)$ & $(1.40)$ \\
fatty acids & $50.46 \mathrm{a}$ & $55.25 \mathrm{~b}$ \\
Total polyunsaturated fatty & $(0.44)$ & $(0.16)$ \\
acids & $46.03 \mathrm{a}$ & $49.78 \mathrm{~b}$ \\
Total $\omega 3$ fatty acids & $(0.08)$ & $(0.47)$ \\
\hline \multirow{2}{*}{ Total $\omega 6$ fatty acids } & $4.43 \mathrm{a}$ & $(1.22)$ \\
\hline \multirow{2}{*}{$\omega 3 / \omega 6$ ratio } & $(0.62)$ & $9.11 \mathrm{a}$ \\
& $10.40 \mathrm{a}$ & $(1.12)$ \\
\hline \multirow{2}{*}{ Polyene index } & $(1.39)$ & $3.09 \mathrm{a}$ \\
& $2.51 \mathrm{a}$ & $(0.22)$ \\
\hline
\end{tabular}

* Average values of three $(n=3)$ replicates. Standard deviations are indicated in brackets. For each fatty acid group or ratio, average values followed by different letters $(a, b)$ denote significant differences $(p<0.05)$ as a result of season.

** Values of fatty acids groups expressed as \% on total FA. 